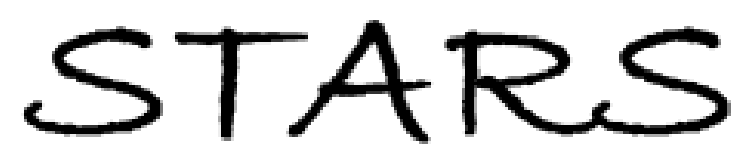

University of Central Florida

STARS

$1-1-2010$

\title{
Investigation of the behavior of serum and plasma in a microfluidics system
}

\author{
J. Caroline Henderson \\ Michele Yacopucci \\ Chang Ju Chun \\ University of Central Florida \\ Keith Lenghaus \\ University of Central Florida \\ Frank Sommerhage \\ University of Central Florida
}

Fiqedn

University of Central Florida Libraries http://library.ucf.edu

This Editorial Material is brought to you for free and open access by the Faculty Bibliography at STARS. It has been accepted for inclusion in Faculty Bibliography 2010 s by an authorized administrator of STARS. For more information, please contact STARS@ucf.edu.

\section{Recommended Citation}

Henderson, J. Caroline; Yacopucci, Michele; Chun, Chang Ju; Lenghaus, Keith; Sommerhage, Frank; and Hickman, James J., "Investigation of the behavior of serum and plasma in a microfluidics system" (2010). Faculty Bibliography 2010s. 242.

https://stars.library.ucf.edu/facultybib2010/242

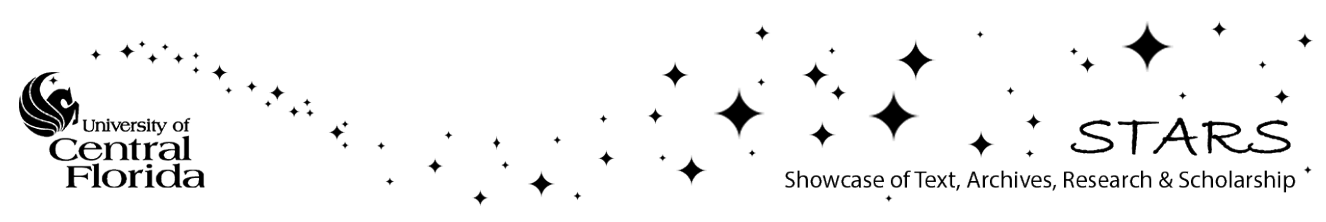




\section{Authors}

J. Caroline Henderson, Michele Yacopucci, Chang Ju Chun, Keith Lenghaus, Frank Sommerhage, and James J. Hickman 


\section{Investigation of the behavior of serum and plasma in a microfluidics system}

J. Caroline Henderson, Michele Yacopucci, ChangJu Chun, Keith Lenghaus, Frank Sommerhage, and James J. Hickman

Citation: Journal of Vacuum Science \& Technology B 28, 1066 (2010); doi: 10.1116/1.3475531

View online: https://doi.org/10.1116/1.3475531

View Table of Contents: https://avs.scitation.org/toc/jvb/28/5

Published by the American Vacuum Society

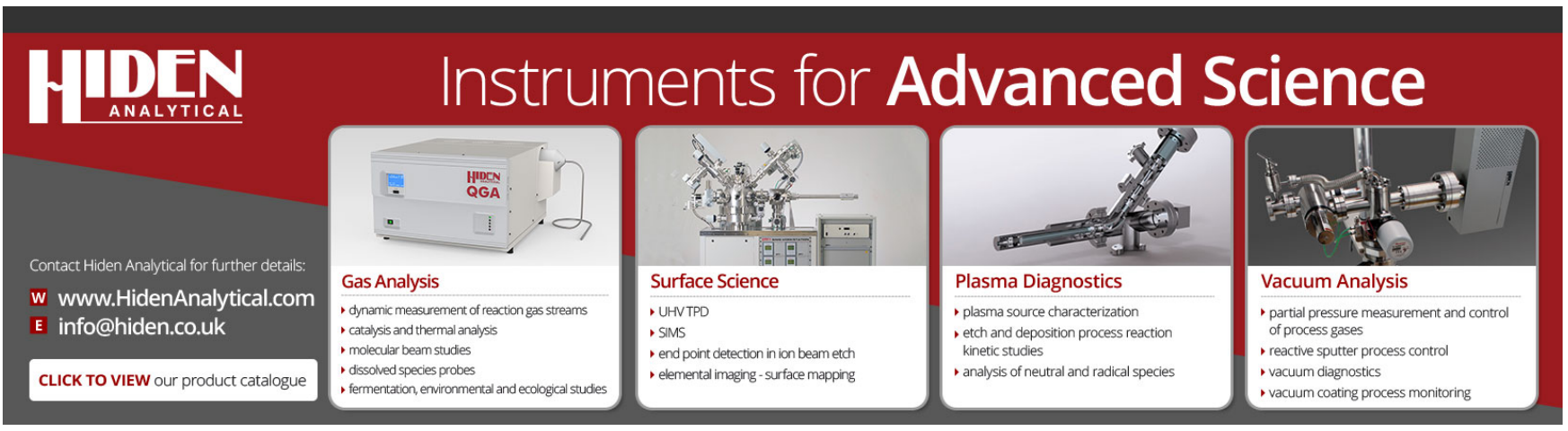




\title{
BRIEF REPORTS AND COMMENTS
}

This section is intended for the publication of (1) brief reports which do not require the formal structure of regular journal articles, and (2) comments on items previously published in the journal.

\section{Investigation of the behavior of serum and plasma in a microfluidics system}

\author{
J. Caroline Henderson and Michele Yacopucci \\ Department of Bioengineering, Clemson University, 401 Rhodes Engineering Research Center, Clemson, \\ South Carolina 29634-0905 \\ ChangJu Chun and Keith Lenghaus \\ Department of Bioengineering, Clemson University, 401 Rhodes Engineering Research Center, Clemson, \\ South Carolina 29634-0905 and NanoScience Technology Center, University of Central Florida, \\ 12424 Research Parkway, Suite 400, Orlando, Florida 32826 \\ Frank Sommerhage \\ NanoScience Technology Center, University of Central Florida, 12424 Research Parkway, Suite 400, \\ Orlando, Florida 32826 \\ James J. Hickman ${ }^{\text {a) }}$ \\ Department of Bioengineering, Clemson University, 401 Rhodes Engineering Research Center, Clemson, \\ South Carolina 29634-0905 and NanoScience Technology Center, University of Central Florida, \\ 12424 Research Parkway, Suite 400, Orlando, Florida 32826
}

(Received 14 January 2009; accepted 12 July 2010; published 30 September 2010)

\begin{abstract}
There are common problems with adsorption of analytes on the surfaces of microfluidic systems with physiological samples such as blood serum, plasma, and urine. The authors' investigation involves the interaction of serum components with fused-silica surfaces under various flow regimes in microcapillaries. Their focus will include the individual components of serum as well as fresh whole serum. The authors studied the whole serum components in our microfluidic system to uncover the responses of proteins in capillary and microchannel surfaces when influenced by the highly variable serum constituents. They have observed the whole serum with a total protein assay by using the bicinchoninic acid assay in combination with a characterization method, such as SDS polyacrylamide gel electrophoresis, and repeated observations for any change of flow rate in fused-silica capillaries (50 $\mu \mathrm{m}$ inside diameter) under continuous flow. The authors' preliminary results contradict anecdotal evidence that proteins and other components of serum clog or prevent flow at steady low flow rates. (C) 2010 American Vacuum Society. [DOI: 10.1116/1.3475531]
\end{abstract}

\section{INTRODUCTION}

Microfluidics, and microelectromechanical systems (MEMS) in general, is a rapidly expanding discipline with industrial, medical, and research applications ranging from capillary electrophoresis to lab-on-a-chip methods. ${ }^{1}$ One perceived benefit of this new technology is that it offers the promise of microscale in vitro and in vivo devices designed to assist with medical procedures and diagnostics such as blood transfusion, drug delivery, biochemical analysis and dialysis due to the low volume of sample needed, ease of sample preparation, and the decrease in analysis time. ${ }^{2} \mathrm{We}$ have investigated the interaction of various types of serum as well as fresh plasma with fused-silica microcapillary surfaces in different flow regimes in an attempt to understand this complex, but important, interaction.

a) Author to whom correspondence should be addressed; electronic mail: jhickman@mail.ucf.edu
Serum is the fluid remaining following the removal of clotting proteins (e.g., fibrinogen and prothrombin) and cells from blood. It is a complex mixture comprised of roughly $8 \%$ protein and $90 \%$ water. The remaining constituents include gases $\left(\mathrm{CO}_{2}, \mathrm{O}_{2}\right.$, and $\left.\mathrm{N}_{2}\right)$, waste products (urea and creatinine), and nutrients (lipids, amino acids, and glucose). Plasma is serum without the removal of the clotting proteins. Many serum components have been used individually as model systems for serum or plasma adsorption due to their binding or sticking properties and they have been investigated under a wide range of flow rates and in a variety of experimental systems. ${ }^{3-6}$

The most characterized components of serum regarding their adsorption characteristics are albumin, immunoglobulin, and alkaline phosphatase, proteins involved in many aspects of biological and bioengineering research. ${ }^{7,8}$ In studies, multiple compounds rarely have been reported in the literature data involving more than three components in a single 
flow regime. However, there exists much anecdotal information concerning the propensity of devices to clog in the presence of complex biological fluids, such as serum or plasma.

There are several clogging problems with physiological samples such as blood, plasma, serum, and urine in analytical and/or diagnostic devices. ${ }^{9-11}$ The high protein content of blood and serum has been shown to be problematic following microsampling in the nebulizers of burner heads and aspiration tubes used in atomic absorption spectroscopy. ${ }^{9,12-16}$ The high-molecular weight proteins in those physiological samples tend to change their structures, lose their function, and precipitate in the injection valve or in the column head. These processes can also produce clogging of chromatography systems, and lead to a rapid decrease of chromatographic performance and an increase in back-pressure in reversedphase liquid chromatography. ${ }^{10,17,18}$ However, little or no experimental evidence exists documenting clogging in the microchannels or microcapillaries of MEMS.

To date the primary purpose of serum and plasma interaction studies with microdevices has been for the development of in vitro testing methods, such as obtaining PCR products from whole blood, ${ }^{19}$ selective elution of antibodies, and protein immobilization and separations, as in capillary electrophoresis. ${ }^{20}$ The adsorption of analytes to the walls of fused-silica capillaries is common in capillary electrophoretic separations as well as other microfluidic devices, and a common cause of flow alteration in those systems. Electrostatic interactions have also been found to be a driving force for the adsorption of cationic polymers (many of which are proteins) at the surface of fused-silica capillaries. $^{11,21,22}$

Our aim was to understand the mechanisms that govern the interaction of proteins in serum and plasma with the surfaces of fused-silica capillaries that then may lead to their clogging, the ultimate goal being to predict the time to failure in microfluidic or other MEMS devices in contact with serum or plasma. Our results indicate that the interactions of different embodiments of serum as well as fresh plasma within a fused-silica microcapillary system under continuous flow or stop-flow conditions did not result in clogging under a variety of experimental protocols. This research offers new insight into the interaction of MEMS and other microscale bioinstrumentation devices with complex biological fluids.

\section{EXPERIMENT}

The interaction of serum and plasma components with fused-silica microcapillary systems was investigated. The bare fused-silica capillaries [Micro SOLVTM CE, inside diameter (i.d.) $=50 \mu \mathrm{m}$ ], cut to 150 or $300 \mathrm{~mm}$ lengths, were glued into luer-lock needles (Precision Glide 20G, $1 \frac{1}{2}$ ) and attached to $10 \mathrm{ml}$ syringes (Beckton Dickinson Latex-free Luer-Lock ${ }^{\mathrm{TM}}$ ) filled with buffer. The syringe was connected to a single channel syringe pump (KD Scientific, Model 100) which was operated at a flow of $100 \mu \mathrm{l} / \mathrm{h}$ at room temperature $\left(24^{\circ} \mathrm{C}\right)$, and the surface was equilibrated overnight. Then the syringe was filled with the liquid of interest (see below) and samples were collected to $1.5 \mathrm{ml}$ flat top microcentrifuge tubes (Fisher Scientific) every $30 \mathrm{~min}$ for $4 \mathrm{~h}$, or daily, over a 3 week period.

Experiments were conducted with the undiluted serum or plasma. A control for each data point was taken from the syringe. Total protein was determined using the BCA method (from Pierce). The assays were conducted in the linear region of the BCA analysis range $(5-500 \mu \mathrm{g} / \mathrm{ml})$, by diluting the samples with phosphate buffered saline, $p \mathrm{H}$ 7.4. The ratio of protein concentrations in the flow through (outlet) to controls (inlet) was expressed as a function of time.

Collected samples were also compared for protein composition by SDS polyacrylamide gel electrophoresis (SDSPAGE) analysis. For protein migration, we used the MiniProtean 3 apparatus and precast polyacrylamide gradient gels (4\%-15\%); for molecular weight determination the Precision Protein Standards solution was loaded onto the gel (all from Bio-Rad). Protein detection was performed by Silver Staining (Gel Code Silver Snap Stain kit II, from Pierce), which offers the possibility to detect less than $10 \mathrm{ng}$ protein levels. Electrophoretically, we also analyzed the profile of proteins desorbed from the fused-silica surface, after serum running. Proteins were desorbed with a $0.2 \%$ SDS buffered solution.

As an example of serum protein interactions with the capillary surface, we determined the alkaline phosphatase activity in eluted samples, using paranitrophenol phosphate as substrate. Enzymes are ultrasensitive probes for protein adsorption in flow systems, and their adsorption behavior can be expressed as cumulative loss. ${ }^{23}$

In this study, we used lyophilized bovine serum (Sigma), liquid bovine serum (Sigma), cell culture grade fetal bovine serum (MediaTech), cell culture grade bovine serum (Atlanta Biologicals), and fresh bovine serum and porcine plasma obtained from Clemson University's Animal Research Center.

Experiments using undiluted serum, as well as plasma, from different sources, at higher flow rates, 500 and $2.4 \mathrm{ml} / \mathrm{h}$, were also performed. Cell culture grade bovine serum was used for the stop-flow experiments over periods of up to 3 weeks. Since it was sterile, it is better suited for long-term experiments. The cell culture grade serum was run through $300 \mathrm{~mm}$ fused-silica capillaries as described above. The long-term flow experiments were designed to monitor any cessation of flow due to clogging. Fresh bovine serum was run at $100 \mu \mathrm{l} / \mathrm{h}$, and elution volume measured at varying intervals, up to 3 days. Each experiment was performed three times and results are given as the average value.

\section{RESULTS AND DISCUSSION}

The investigation was concerned with the interaction of serum and plasma components with fused-silica microcapillary surfaces. The anticipated result was clogged by proteins and subsequent cessation of flow. Furthermore, we were interested in understanding and controlling the initial processes to prevent this from occurring or to predict its occurrence.

In Fig. 1, we compare the adsorption behavior of three commercially available bovine serum samples, on fusedsilica capillaries. The ratio of the eluted protein concentra- 


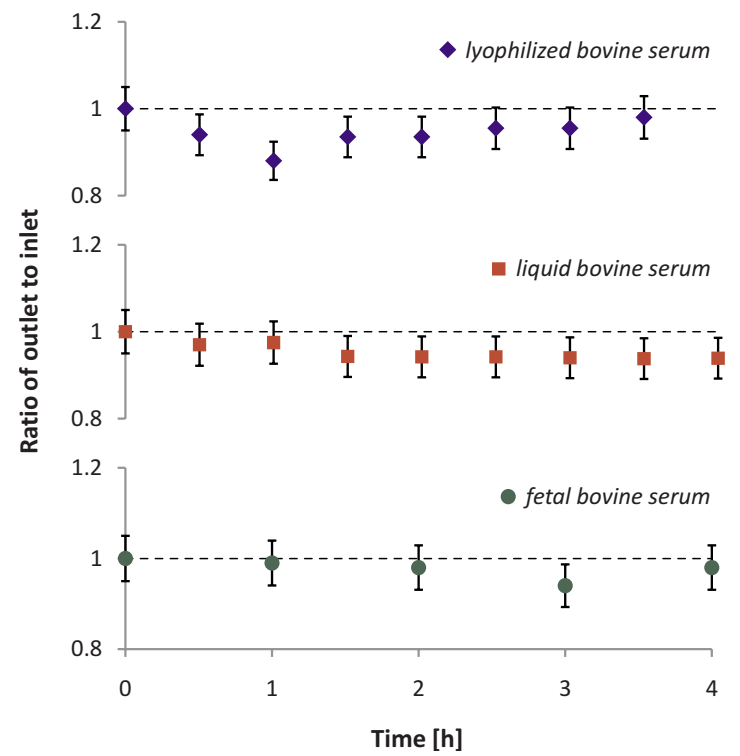

FIG. 1. (Color online) Ratio of outlet (sample) to inlet (control) protein concentration of lyophilized bovine serum $(87 \mathrm{mg} / \mathrm{ml})$ through fused-silica capillary $(50 \mu \mathrm{m} / 150 \mathrm{~mm})$ under continuous flow $(100 \mu \mathrm{l} / \mathrm{h})$, liquid bovine serum $(75 \mathrm{mg} / \mathrm{ml})$ through fused-silica capillary $(50 \mu \mathrm{m} / 300 \mathrm{~mm})$ under continuous flow $(500 \mu \mathrm{l} / \mathrm{h})$, and fetal bovine serum proteins $(70$ $\mathrm{mg} / \mathrm{ml})$ through fused-silica capillary $(50 \mu \mathrm{m} / 300 \mathrm{~mm})$ under continuous flow $(500 \mu \mathrm{l} / \mathrm{h})$

A

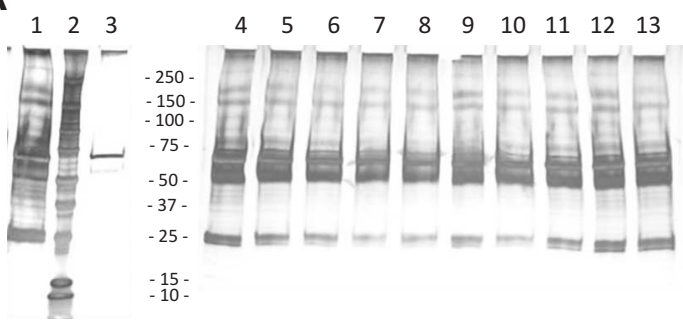

B

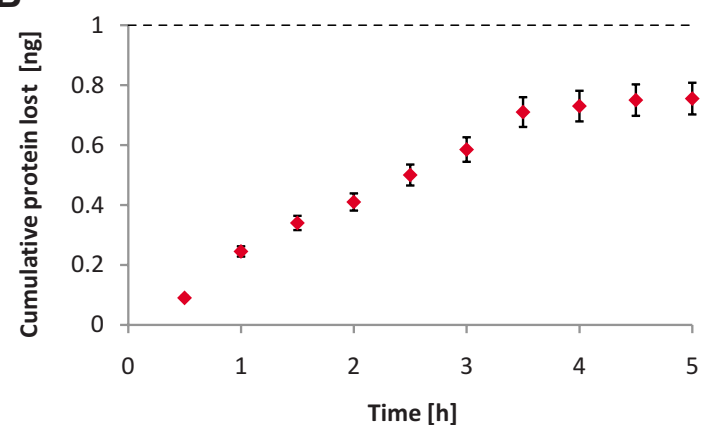

FIG. 2. (Color online) (a) SDS-PAGE analysis of bovine serum samples after flowing through fused-silica capillaries $(50 \mu \mathrm{m} / 150 \mathrm{~mm})$ under continuous flow $(100 \mu \mathrm{l} / \mathrm{h})$. The lanes represent (1) control bovine serum (inlet), (2) molecular weight standards, (3) proteins desorbed from the capillary wall, and (4-13) serum protein samples collected every 30 min during running through capillaries (outlet). (b) Activity analysis of bovine serum alkaline phosphatase in eluted samples collected at outlet of fused-silica capillary $(50 \mu \mathrm{m} / 150 \mathrm{~mm})$ under continuous flow $(100 \mu \mathrm{l} / \mathrm{h})$.
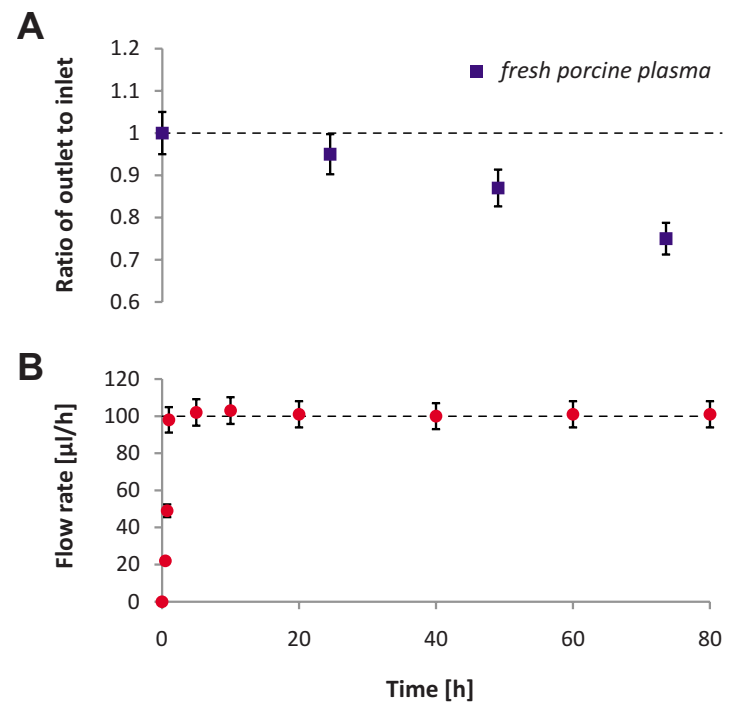

FIG. 3. (Color online) (a) Ratio of outlet (sample) to inlet (control) protein concentration of fresh porcine plasma through fused-silica capillary $(50 \mu \mathrm{m} / 300 \mathrm{~mm})$ under continuous flow $(100 \mu \mathrm{l} / \mathrm{h})$ over a 3 day period. (b) Long-term flow rate change monitored with fresh bovine serum through a $150 \mathrm{~mm}$ long and $50 \mu \mathrm{m}$ i.d. fused-silica capillary system, at a flow rate of $100 \mu \mathrm{l} / \mathrm{h}$.

tion (outlet) compared to that of the control (inlet) shows little variation, which indicates low levels of protein loss. Differences in protein levels between lyophilized and liquid bovine serum were not noted, suggesting that lyophilization does not alter flow properties of serum proteins. The particular composition of fetal bovine serum does not seem to affect the adherence of proteins to fused-silica-modified surfaces.

The use of BCA to monitor serum protein adsorption in microfluidic systems is limited to $0.5-20 \mu \mathrm{g} / \mathrm{ml}$, so no indication of nanogram level deposition on the surface of the microcapillary can be given for this system (which is in the protein monolayer range). Therefore, additional methods of investigation with increased detection capabilities were selected, such as SDS-PAGE and enzyme assays. Figure 2(a) shows the SDS-PAGE analysis of serum samples collected from our microfluidic system, which essentially validated the adsorption behavior observed by the BCA method. The electrophoretical profile revealed a decrease of protein concentration from all separated fractions, especially in the first $4 \mathrm{~h}$ (lanes 4-11). The protein solution composition after desorption from the capillary surface with SDS showed that albu$\min (\mathrm{MW}=66 \mathrm{kD})$ had a high affinity for the fused-silicamodified surface.

These results prompted an investigation into the adsorption of individual serum proteins. Alkaline phosphatase had been selected, which allows the detection of proteins adsorbed at nanogram levels [Fig. 2(b)]. The adsorption pattern suggests that in the first $4 \mathrm{~h}$ alkaline phosphatase adheres continuously to surfaces, probably concomitantly with other serum proteins. Afterwards, its adsorption is limited, possibly due to the competition with other proteins. 
As compared to serum, fresh porcine plasma proteins show a significant affinity toward fused-silica surfaces [Fig. $3(\mathrm{a})$. This may be explained by the presence of sticky clotting proteins, such as fibronectin, fibrinogen, and prothrombin. However, even during extended running periods, no protein clogging was noted. Long-term flow experiments [Fig. $3(b)]$ indicated that the flow rate of fresh bovine serum was maintained at a constant level over a period of up to 3 days.

Anecdotal evidence had previously suggested that serum clogs microcapillaries. ${ }^{9-11}$ Experimental evidence, based on capillary electrophoresis, suggested that flow rates could be altered due to electrochemical interactions and subsequent adsorption of proteins. ${ }^{22,24}$ However, our research indicated that in the case of pressure driven flow, in spite of low level of protein adsorption (nanogram levels), no significant clogging or alteration in flow rates occurred over a 3 day period. Future studies are required to identify and quantify proteins adsorbed at submonolayer level.

\section{CONCLUSIONS}

In our study, we showed that clogging of capillaries by serum proteins does not occur in a microfluidic system consisting of fused-silica surfaces, contradicting anecdotal evidence that rapid failure could be expected in a microfluidics system exposed to high protein content solutions such as serum. This is the first reported systematic study of serum and plasma flow in microfluidic devices. These data should be useful to the entire bioMEMS community in designs for devices with applications in biotechnology and medical systems.

\section{ACKNOWLEDGMENTS}

The authors wish to thank the MTO and DSO offices of DARPA for funding under Grant No. 560-7034-200-2002536 and the NSF for funding from Grant No. 206-2002012.

${ }^{1}$ J. Knight, Nature (London) 418, 474 (2002).

${ }^{2}$ L. B. Koutny, D. Schmalzing, T. A. Taylor, and M. Fuchs, Anal. Chem. 68, 18 (1996).

${ }^{3}$ A. L. Adams, G. C. Fischer, P. C. Munoz, and L. Vroman, J. Biomed. Mater. Res. 18, 643 (1984).

${ }^{4}$ L. Vroman, A. L. Adams, G. C. Fischer, P. C. Munoz, and M. Stanford, Adv. Chem. Ser. 199, 265 (1982).

${ }^{5}$ L. Vroman and A. L. Adams, J. Colloid Interface Sci. 111, 391 (1986).

${ }^{6}$ P. Wojciechowski and J. L. Brash, J. Biomater. Sci., Polym. Ed. 2, 203 (1991).

${ }^{7}$ M. A. Rothschild, M. Oratz, and S. S. Schreiber, Hepatology (Philadelphia, PA, U. S.) 8, 385 (1988).

${ }^{8}$ H. N. Fernley, in The Enzymes, edited by P. D. Boyer (Academic, New York, 1971), Vol. 4, p. 424.

${ }^{9}$ H. K. Matusiewicz, Anal. Chim. Acta 136, 215 (1982).

${ }^{10}$ M. C. García Alvarez-Coque and S. Carda Broch, J. Chromatogr., B: Biomed. Sci. Appl. 736, 1 (1999).

${ }^{11}$ J. K. Towns and F. E. Regnier, Anal. Chem. 64, 2473 (1992).

${ }^{12}$ K.-T. Lee and E. Jacob, Mikrochim. Acta 62, 65 (1974).

${ }^{13}$ E. J. Ekanem, Bull. Chem. Soc. Jpn. 57, 2979 (1984).

${ }^{14}$ J. Savory, J. W. Wiggins, and M. G. Heintges, Am. J. Clin. Pathol. 51, 720 (1969).

${ }^{15}$ D. C. Manning, At. Absorption Newsl. 14, 99 (1975).

${ }^{16}$ J. L. Hansen, Am. J. Med. Technol. 34, 625 (1968).

${ }^{17}$ L. J. C. Love, S. Zibas, J. Noroski, and M. Arunyanart, J. Pharm. Biomed. Anal. 3, 511 (1985).

${ }^{18}$ K. H. Bui and S. B. French, J. Liq. Chromatogr. Relat. 12, 861 (1989).

${ }^{19}$ N. Zhang, H. Tan, and E. S. Yeung, Anal. Chem. 71, 1138 (1999).

${ }^{20}$ H. Mao, T. Yang, and P. S. Cremer, Anal. Chem. 74, 379 (2002).

${ }^{21}$ J. K. Towns and F. E. Regnier, Anal. Chem. 63, 1126 (1991).

${ }^{22}$ S. Ghosal, Anal. Chem. 74, 771 (2002).

${ }^{23}$ K. Lenghaus, J. W. Dale, J. C. Henderson, D. C. Henry, E. R. Loghin, and J. J. Hickman, Langmuir 19, 5971 (2003).

${ }^{24}$ A. R. Minerick, A. E. Ostafin, and H.-C. Chang, Electrophoresis 23, 2165 (2002). 